Vol.61: e18180104, 2018

http://dx.doi.org/10.1590/1678-4324-2018180104

ISSN 1678-4324 Online Edition
BRAZILIAN ARCHIVES OF BIOLOGY AND TECHNOLOGY

\title{
Antinociceptive and Anti-inflammatory Activities of Marine Sponges Aplysina Caissara, Haliclona sp. and Dragmacidon Reticulatum
}

\author{
Mariana Appel Hort ${ }^{1 *}$, Flavio Manoel Rodrigues da Silva Júnior ${ }^{1}$, Edariane Menestrino \\ Garcia $^{1}$, Gianni Goulart Peraza1, Andrea Soares ${ }^{2}$, Clea Lerner ${ }^{\mathbf{3}}$, Ana Luiza Muccillo-Baisch ${ }^{\mathbf{1}}$. \\ ${ }^{1}$ Instituto de Ciências Biológicas - Universidade Federal do Rio Grande, Rio Grande, Rio Grande do Sul Brazil $;{ }^{2}$ Gota \\ D’água, Florianópolis, Santa Catarina, Brazil; ${ }^{3}$ Fundação Zoobotânica do Rio Grande do Sul, Porto Alegre, Rio \\ Grande do Sul, Brazil.
}

\begin{abstract}
Marine sponges are a rich source of bioactive natural products with multiple pharmacological properties. In this study, the anti-inflammatory and antinociceptive effects of extracts obtained from Aplysina caissara, Haliclona sp. and Dragmacidon reticulatum were evaluated by using the writhing test and formalin-induced mouse paw edema model in mice. All extracts were administered via oral pathway in the doses of 60 and $90 \mathrm{mg} / \mathrm{kg}$. In the writhing test the pretreatment with all sponges resulted in significant inhibition of the acetic acid-induced response, suggesting an antinociceptive effect. The formalin test showed that the extracts from A. caissara, Haliclona sp. and D. reticulatum, in the tested doses, did not affect the first formalin phase, however, they were effective in the late phase. To assess the potential anti-inflammatory activity of the extracts, the test of formalin-induced paw edema was used. The oral administration of A. caissara, Haliclona sp. and D. reticulatum extracts significantly reduced the formalin-induced paw edema in mice. In conclusion, our data show that marine sponges can be an important source of anti-inflammatory and antinocicpetive products that can be promising therapeutical leads. Furthermore, pharmacological and chemical studies have been developed not only to characterize the mechanism(s) that is/are responsible for the antinociceptive and antiinflammatory action but also to identify the active principles of sponges.
\end{abstract}

Keywords: inflammation; nociception; marine sponges.

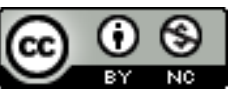

* Author for correspondence: marianaappel@gmail.com 


\section{INTRODUCTION}

Marine organisms (bacteria, fungi, micro-algae, sponges, mollusks and other invertebrates) are sources of numerous new compounds with multiple pharmacological properties ${ }^{1-5}$. Regarding the diversity of marine organisms, the phylum of sponges is the most productive. The phylum Porifera, which is found in both sea surface and deep waters, besides having a few freshwater species, is traditionally known to be a promising source of bioactive metabolites ${ }^{6}$.

Sponge-derived bioactive substances have possessed antibacterial, antiviral, antifungal, antimalarial, antihelminthic, immunosuppressive, muscle relaxants, anti-inflammatory and analgesic activities ${ }^{7}$. The search for new anti-inflammatory and analgesic agents from marine sources has yielded several promising therapeutic leads. Several sponges' species and isolated sponges derived compounds have been described by their effects. Some examples of sponge species with anti-inflammatory activity includes Fasciospongia cavernosa, Petrosia contignata, Cacospongia linteiformis ${ }^{5}$, Luffariella variabilis ${ }^{8}$, Xestospongia testudinaria ${ }^{9}$ and Aplysina fistularis ${ }^{10}$. Some of the reported mechanisms involved in the anti-inflammatory effects of marine sponges metabolites were the inhibition of phospholipase A2, inhibition of interleukin-1 mediated prostaglandin synthesis, inhibition of cicloxigenase and reduction of superoxide production by neutrophils ${ }^{11,12}$. The analgesic potential of sponges is less explored and was already evidenced for Aplysina caissara. ${ }^{13}$

Our study was conducted with three species of marine sponges, Haliclona sp., Dragmacidon reticulatum and Aplysina caissara. Sponges of the genus Haliclona are well-known for producing a variety of secondary metabolites, many of them are cytotoxic ${ }^{14,15}$, antifungal ${ }^{16}$, antimicrobial ${ }^{17}$ and anti-inflammatory ${ }^{18,19}$. The specie D. reticulatum produce some secondary metabolites that are cytotoxic, antimicrobial, antiprotozoal and antiviral ${ }^{20}$.

The specie A. caissara, an endemic Brazilian specie of marine sponges, is rich in active peptides and alkaloids ${ }^{21,22}$. Our laboratory studies have indicated that aqueous extracts of A. caissara, administered intraperitoneally show antinociceptive and anti-inflammatory profiles ${ }^{13}$. Besides, the anti-tuberculosis and cytotoxic activity was also shown in vitro ${ }^{22}$. More recently, Medeiros et al. ${ }^{10}$ showed that an isolated compound from Aplysina fistularis present anti-inflammatory effects in macrophages cell line.

The purpose of this study was to investigate the anti-inflammatory and antinociceptive activities of extracts from A. caissara, Haliclona sp. and D. reticulatum, sponges that are abundant in Brazil, by using the writhing test and formalin-induced mouse paw edema model. We have also compared the effects of the extracts between them and with a nonsteroidal anti-inflammatory drug (diclophenac) and morphine.

\section{MATERIALS AND METHODS}

\section{Chemicals}

Diclofenac (Voltaflan ${ }^{\circledR}$ ) and morphine (Dinomorf®) were kindly provided by the University Hospital Dr. Miguel Riet Corrêa Jr from Universidade Federal do Rio Grande. Formaldehyde and acetic acid were purchased from Delaware ${ }^{\circledR}$ (Porto Alegre, RS, Brazil). The extracts and drugs were dispersed or dissolved in saline solution $(0.9 \% \mathrm{NaCl})$ for administration.

Braz. Arch. Biol. Technol. v.61: e18180104 2018 


\section{Sponge Material}

Samples of A. caissara, Haliclona sp. e D. reticulatum were collected on Arvoredo Island (Florianópolis, SC, Brazil) in April 2006 at a depth of $7 \mathrm{~m}$. They were washed in sea water and all visible surface debris was removed. Afterwards, they were rapidly washed in freshwater and immediately frozen. The frozen samples were also immersed in ethanol and maintained at $-20^{\circ} \mathrm{C}$. The specimens were identified by Clea Lerner, $\mathrm{PhD}$, and kept in the Museu de Ciências Naturais, Fundação Zoobotânica of Rio Grande do Sul, Brazil Porífera collection (MCNPOR).

\section{Extract Preparation}

The extract was prepared according to the following procedure: the sponges were extracted in ethanol and the remaining material was sequentially extracted four times with methanol $(0.3 \mathrm{~g} / \mathrm{mL})$ by maceration for 4 days. After the fourth day, the ethanol and methanol solutions were blended and filtered. After filtration, the extracted material was concentrated in a rotary evaporator (Fisaton, Brazil) and the final extract was partitioned against hexane $(1: 1 \mathrm{v} / \mathrm{v})$. The final extract was dried in SpeedVac (SPD1010; ThermoSavant, NY, USA) ${ }^{13}$.

\section{Animals}

Male Swiss albino mice (25-35 g) were provided by the Animal House of the Universidade Federal do Rio Grande (FURG), were housed in rooms at controlled temperature $\left(20-22^{\circ} \mathrm{C}\right)$, in 12-h : 12-h light/dark cycles. Standard rodent diet and tap water were provided ad libitum. The experiments were performed after approval of the protocol by the Institutional Ethics Committee in agreement with the guidelines of the Brazilian National Council for Control of Animal Experimentation.

\section{Antinociceptive Activity}

\section{Writhing Test}

The abdominal writhing response to the acetic acid administration $(0.6 \%, 10 \mathrm{~mL} / \mathrm{kg}$, i.p. $)$ consists of contractions of the hind limbs ${ }^{23}$. For the writhing test, mice got the acetic acid injection $30 \mathrm{~min}$ after getting their respective treatments ( $\mathrm{n}=8$ animals/group). Animals were treated with the A. caissara extract ( 60 and $90 \mathrm{mg} / \mathrm{kg}$ ), Haliclona sp. extract (60 and $90 \mathrm{mg} / \mathrm{kg}$ ), D. reticulatum extract (60 and $90 \mathrm{mg} / \mathrm{kg}$ ) or saline (control group) $(0.9 \% ; 0.1$ $\mathrm{mL} / 10 \mathrm{~g}$ ) by oral pathway (gavage). One group was treated with the reference opioid analgesic, morphine $(2.0 \mathrm{mg} / \mathrm{kg}) 60 \mathrm{~min}$ prior to the acetic acid injection by intraperitoneal pathway (i.p.) and another group received diclofenac ( $5 \mathrm{mg} / \mathrm{kg}$; i.p.), also $60 \mathrm{~min}$ prior to the acetic acid injection, an anti-inflammatory non-steroidal drug. The number of abdominal writhing was counted cumulatively for $25 \mathrm{~min}$, starting 5 min after the administration. Antinociception was calculated as a percentage of inhibition of writhing constrictions by using the formula [(control group mean - test group mean)/(control group)] 100\%. 


\section{Formalin Test}

In this test, $20 \mu \mathrm{L}$ of $2.5 \%$ formalin was injected into the left hind paws of mice 30 or 60 min after they had been submitted to their respective treatments ( $\mathrm{n}=8$ animals/group). Animals were treated with the A. caissara extract (60 and $90 \mathrm{mg} / \mathrm{kg}$ ), Haliclona sp. extract (60 and $90 \mathrm{mg} / \mathrm{kg}$ ), D. reticulatum extract (60 and $90 \mathrm{mg} / \mathrm{kg}$ ) or saline (control group) $(0.9 \% ; 0.1 \mathrm{~mL} / 10 \mathrm{~g}$ ) by oral pathway (gavage) $30 \mathrm{~min}$ prior to formalin injection. One group was treated (60 min prior to the formalin injection) with the opioid analgesic morphine $(2.0 \mathrm{mg} / \mathrm{kg}$; i.p.) and another group received diclofenac $(5 \mathrm{mg} / \mathrm{kg}$; i.p.), also 60 min prior to the formalin injection, an anti-inflammatory non-steroidal drug. The formalin-induced paw licking was considered an indicator of nociceptive behavior. The amount of time that each animal spent licking the paw was recorded during two 5-min intervals: the first one began immediately after the injection (first phase) and the second one began 20 min after the injection (second phase) ${ }^{24}$. The total time spent in licking the injected paw was recorded and used for quantifying the nociceptive behavior.

\section{Anti-Inflammatory Activity}

\section{Formalin-Induced Paw Edema}

The anti-inflammatory activity of Haliclona sp. and $D$. reticulates extracts were assessed by paw edema test in mice ${ }^{25}$. Before formalin injection $(20 \mu \mathrm{L} ; 2.5 \%$, ) the volume of each mouse paw was measured separately by means of a plethysmometer (Letica, Barcelona, Spain). Thirty minutes after the administration (by gavage) of the A. caissara extract (60 and $90 \mathrm{mg} / \mathrm{kg})$, Haliclona sp. extract (60 and $90 \mathrm{mg} / \mathrm{kg})$, D. reticulatum $(60$ and $90 \mathrm{mg} / \mathrm{kg}$ ) or saline (control group) $(0.9 \% ; 0.1 \mathrm{~mL} / 10 \mathrm{~g}$ ) to the mice, acute inflammatory edema was induced by sub plantar injection of formalin into the right hind paws of mice ( $\mathrm{n}=8$ animals/group). The edema caused by formalin was measured at 30 and $180 \mathrm{~min}$ after formalin injection. Diclofenac $(5 \mathrm{mg} / \mathrm{kg}$; i.p.) was used as positive control. The volume of the edema was expressed for each animal as the difference between before and after formalin injected paws.

\section{Statistical Analysis}

Results were expressed as mean \pm SEM (standard error of mean). Data were analyzed by one way analysis of variance followed by Tukey's post hoc test. Values of $p<0.05$ were considered statistically significant.

\section{RESULTS AND DISCUSSION}

This study reports the antinociceptive and anti-inflammatory effects induced by extracts obtained from three sponges, A. caissara, Haliclona sp. and D. reticulatum, in mice. The antinociceptive and anti-inflammatory activities were evaluated by the acetic acid-induced writhing response and the formalin test.

To evaluate the possible analgesic effect of the sponges, we used the writhing test, that is commonly used for screening peripherally active analgesic. In this test, acetic acid acts indirectly inducing the release of endogenous mediators that stimulate the nociceptive neurons which are sensitive to non-steroidal anti-inflammatory drugs and opioids. In the 
writhing test, the acetic acid-induced writhing response, the nociceptive response appears to result from the release of TNF- $\alpha$, interleukin- $1 \beta$ and interleukin- 8 by resident peritoneal macrophage and mast cells ${ }^{26}$, the release of biogenic amines (e.g., histamine and serotonin), cyclooxygenases and their metabolites (e.g., PGE 2 and PGF2 $\alpha$ ) ${ }^{27}$ and opioid mechanisms ${ }^{28}$. The participation of eicosanoids and sympathomimetic amines in the nociceptive responses induced by acetic acid has also been demonstrated ${ }^{29,30}$.

Our results showed that pre-treatment with all sponges resulted in significant inhibition of the acetic acid-induced writhing response. All extracts were evaluated at doses of 60 and $90 \mathrm{mg} / \mathrm{kg}$ by oral pathway. Results in Table 1 show that the oral administration of both doses of aqueous extract of $A$. caissara inhibited the acetic acid-induced abdominal constriction (62.8 and $60.1 \%$ - $p<0.001$, respectively). Similar results were obtained by both oral doses of aqueous extract of Haliclona sp. in the acetic acid-induced abdominal constriction (50.2 and $71.2 \%-p<0.001$, respectively). The two doses of the extract of $D$. reticulatus also significantly inhibited the acetic acid-induced abdominal constriction (27.5 and 29.3\% - $p<0.05$ ), however it was less effective than A. caissara and Haliclona sp. Furthermore, the antinociceptive effects in the test were also observed for diclofenac $(62.4 \%-p<0.001)$, used as the reference peripheral analgesic drug and for morphine (97.1\% - $p<0.001$ ), used as the reference central analgesic drug (Table 1). These data suggest the possible antinociceptive action of the extracts from A. caissara, Haliclona sp. and $D$. reticulatum. In addition, they also corroborate a previous study of the antinociceptive activity of $A$. caissara ${ }^{13}$. Here, both doses of A. caissara and Haliclona $\mathrm{sp}$. were as potent as diclofenac in the inhibition of constrictions in mice.

Table 1. Effect of A. caissara, Haliclona sp. and D. reticulatum extracts on acetic acid-induced writhing behavior in mice.

\begin{tabular}{l|cc}
\hline \multicolumn{1}{c|}{ Group } & $\begin{array}{c}\text { Number of abdominal } \\
\text { constrictions (during 25 min) }\end{array}$ & $\begin{array}{c}\text { \% of writhes } \\
\text { inhibition }\end{array}$ \\
\hline Control & $101.3 \pm 5.5$ & - \\
Morphine $(2 \mathrm{mg} / \mathrm{kg})$ & $2.9 \pm 1.6^{* * * *}$ & 97.1 \\
Diclofenac $(5 \mathrm{mg} / \mathrm{kg})$ & $38.1 \pm 2.1^{* * *}$ & 62.4 \\
A. caissara $(60 \mathrm{mg} / \mathrm{kg})$ & $37.7 \pm 6.3^{* * *}$ & 62.8 \\
A. caissara $(90 \mathrm{mg} / \mathrm{kg})$ & $40.5 \pm 5.5^{* * *}$ & 60.1 \\
Haliclona sp. $(60 \mathrm{mg} / \mathrm{kg})$ & $50.4 \pm 5.8^{* * *}$ & 50.2 \\
Haliclona $\mathrm{sp.}(90 \mathrm{mg} / \mathrm{kg})$ & $29.2 \pm 6.1 * * *$ & 71.2 \\
D. reticulatus $(60 \mathrm{mg} / \mathrm{kg})$ & $73.4 \pm 7.3^{*}$ & 27.5 \\
D. reticulatus $(90 \mathrm{mg} / \mathrm{kg})$ & $71.6 \pm 8.9^{*}$ & 29.3 \\
\hline
\end{tabular}


The number of abdominal constrictions are expressed as mean \pm SEM. All extracts and saline (control group) were administered by oral pathway ( $\mathrm{n}=8$ animals/group). Morphine and diclofenac were administrated by intraperitoneal pathway. $* * * p<0.001 ; * \mathrm{p}<0.05$ indicates statistical difference when compared to control (one-way ANOVA followed by Tukey post hoc test).

Neurogenic and inflammatory pain was evaluated by using the formalin test. In this test, the initial pain (early phase) is explained as a direct stimulation of nociceptors and reflects centrally mediated pain, whereas the late phases are thought to be secondary to the inflammatory reactions ${ }^{24}$. The first phase corresponds to acute neurogenic pain while the second phase corresponds to inflammatory pain. Experimental results have demonstrated that several mediators, such as substance $\mathrm{P}$ and bradykinin, participate in the early phase, while histamine, serotonin, prostaglandins, nitric oxide and bradykinin, released from damaged cells, take part in the inflammatory response. Besides, they are involved in the late phase of the formalin test ${ }^{31}$. Drugs that act primarily on the central nervous system inhibit both phases equally, while peripherally acting drugs inhibit the late phase ${ }^{32}$. Therefore, second phase behaviors are selectively attenuated by cyclooxygenase inhibitors whereas first and second phase behaviors are attenuated by opioids ${ }^{33}$.

The extracts from A. caissara, Haliclona sp. and D. reticulatum, in the tested doses, did not affect the first formalin phase, however, they were effective in the late phase ( $\mathrm{p}<$ 0.001 ), as demonstrated in the Figure 1 and Table 2. It suggests that peripheral mechanism is involved in its effects and may also exhibit an associated anti-inflammatory effect since the anti-inflammatory drugs exhibited some effect in this phase. This is consistent with our results that show the effectiveness of diclofenac (as positive control in this study) in the late phase ( $74.2 \%$ of inhibition), but not in the early one. Previous results showed that the i.p. administration of the extract of A. caissara in the formalin test inhibited the licking behavior significantly ${ }^{13}$, during both early and late phases. In contrast, in this study, the extract administrated by oral pathway was not capable to reduce the first phase of formalin test. It seems that the systemic administration can be more effective in reduce the acute neurogenic pain (first phase) in mice. There are no previous data in the literature showing the antinociceptive effects of Haliclona sp. and D. reticulatum. The results from the writhing and formalin tests indicate the potential antinociceptive effect of the three sponges extracts.

Since the reduction of the second phase in the formalin test implied that there might be an anti-inflammatory mechanism, we decided to evaluate the effects of extracts from sponges on peripheral inflammation. By using formalin as a stimulus, we could produce an acute inflammatory response after $3 \mathrm{~h}$ in the paws of mice. The role played by inflammatory mediators, such as bradykinin, interleukin (IL)-1 $\beta$, IL-6, IL-8 and tumor-necrosis factor- $\alpha$ $(\mathrm{TNF}-\alpha)^{34}$, eicosanoids and nitric oxide ${ }^{24,35}$ in the response induced by formalin has been demonstrated. Anti-inflammatory compounds are likely to have suppressed the edema formation by the inhibition of the inflammatory mediator substances. 


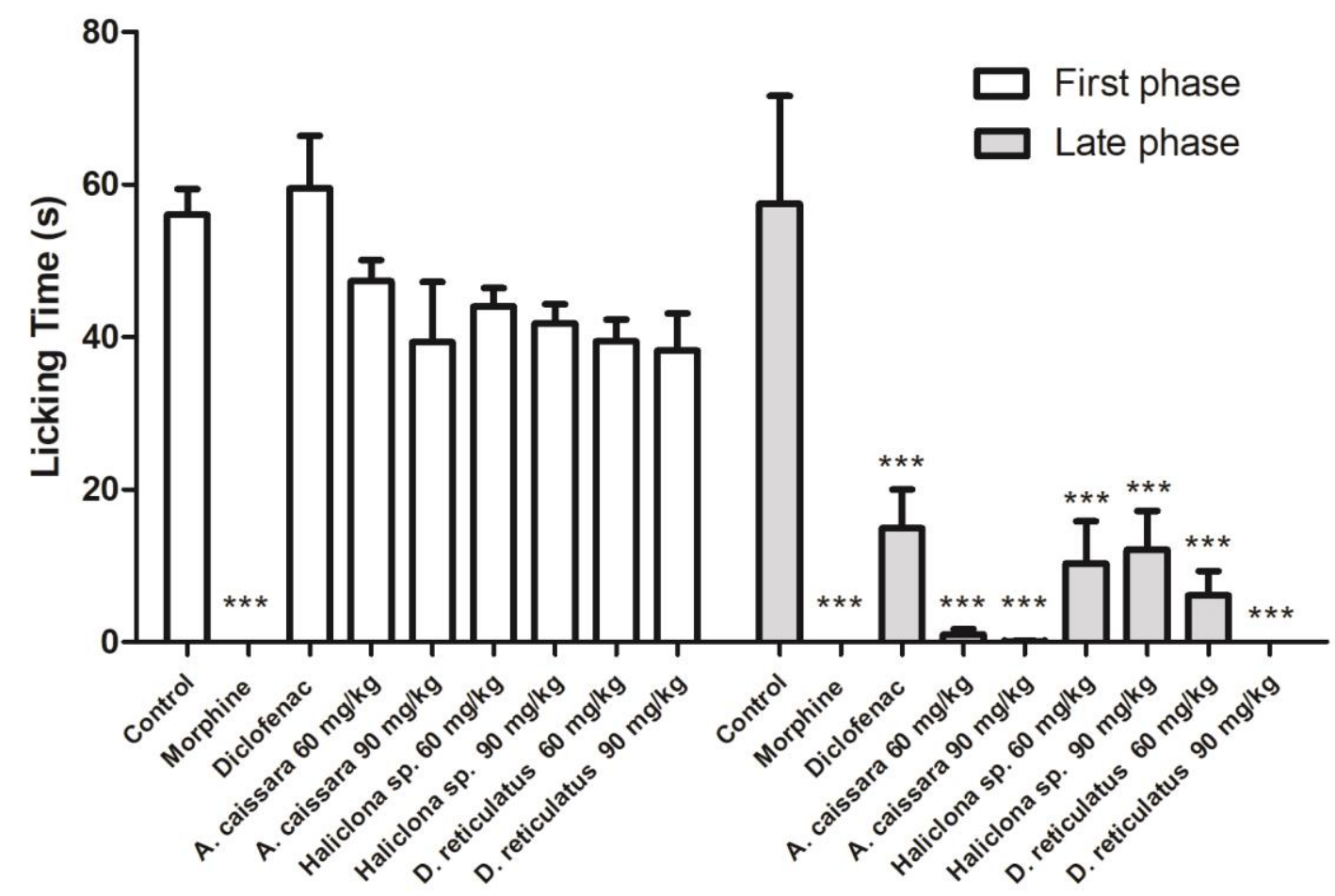

Figure 1: Antinociceptive effect of $A$. caissara, Haliclona $s p$. and $D$. reticulatum extracts on formalin-induced pain in mice. The amount of time spent in licking the injected paw was recorded in two phases: first phase: $0-5$ min postformalin injection; second phase: $20-25$ min post-injection. Values are expressed as mean \pm SEM. All extracts and saline (control group) were administered by oral pathway ( $\mathrm{n}=8$ animals/group). Morphine and diclofenac were administrated by intraperitoneal pathway. $* * *$ p $<0.001$ indicates statistical difference when compared to control (oneway ANOVA followed by Tukey post hoc test). 
Table 2: Percentage of inhibition of A. caissara, Haliclona sp. and D. reticulatum extracts on formalin-induced pain in mice.

\begin{tabular}{l|cc}
\hline \multicolumn{1}{c|}{ Group } & $\begin{array}{l}\text { First } \\
\text { Inhibition (\%) }\end{array}$ & $\begin{array}{l}\text { Lhase phase } \\
\text { Inhibition (\%) }\end{array}$ \\
\hline Control & - & - \\
Morphine $(2 \mathrm{mg} / \mathrm{kg})$ & 100 & 100 \\
Diclofenac $(5 \mathrm{mg} / \mathrm{kg})$ & - & 74.2 \\
A. caissara $(60 \mathrm{mg} / \mathrm{kg})$ & 15.5 & 98.3 \\
A. caissara $(90 \mathrm{mg} / \mathrm{kg})$ & 29.8 & 99.8 \\
Haliclona sp. $(60 \mathrm{mg} / \mathrm{kg})$ & 21.5 & 82.1 \\
Haliclona $\mathrm{sp} .(90 \mathrm{mg} / \mathrm{kg})$ & 25.3 & 79.0 \\
D. reticulatus $(60 \mathrm{mg} / \mathrm{kg})$ & 29.5 & 89.3 \\
D. reticulatus $(90 \mathrm{mg} / \mathrm{kg})$ & 31.8 & 100 \\
\hline
\end{tabular}

The amount of time spent in licking the injected paw was recorded in two phases: first phase: $0-5$ min post-formalin injection; second phase: 20-25 min post-injection. Resuls are expressed as percentage of inhibition of the licking time. All extracts and saline (control group) were administered by oral pathway ( $\mathrm{n}=8$ animals/group). Morphine and diclofenac were administrated by intraperitoneal pathway.

In this study, oral administration of A. caissara, Haliclona sp. and D. reticulatum extracts reduced the formalin-induced paw edema in mice. Table 3 shows that A. caissara (60 and $90 \mathrm{mg} / \mathrm{kg}$ ) and Haliclona sp. (60 and $90 \mathrm{mg} / \mathrm{kg}$ ) significantly reduced the formalininduced hind paw edema in rats in $28.8(\mathrm{p}<0.001)$ and $24.4 \%(\mathrm{p}<0.01)$; and $20.0(\mathrm{p}<0.05)$ and $28.9 \%$ ( $\mathrm{p}<0.001$ ), respectively. Under the same experimental conditions $D$. reticulatum significantly only reduced the formalin-induced edema in the higher dose $(90$ $\mathrm{mg} / \mathrm{kg})$ in $26.7 \%(\mathrm{p}<0.001)$. The effects were similar to the one obtained by diclofenac (positive control). 
Table 3. Effect of A caissara, Haliclona sp. and D. reticulatum extract on formalin-induced hind paw edema in mice.

\begin{tabular}{l|cc}
\hline \multicolumn{1}{c|}{ Group } & $\begin{array}{c}\text { Paw edema }(\boldsymbol{m L}) \\
\text { 3h after formalin }\end{array}$ & \% of inhibition \\
\hline Control & $0.45 \pm 0.01$ & \\
Diclofenac $(5 \mathrm{mg} / \mathrm{kg})$ & $0.35 \pm 0.03^{* *}$ & 22.2 \\
A. caissara $(60 \mathrm{mg} / \mathrm{kg})$ & $0.32 \pm 0.02 * * *$ & 28.8 \\
A. caissara $(90 \mathrm{mg} / \mathrm{kg})$ & $0.34 \pm 0.02^{* *}$ & 24.4 \\
Haliclona sp. $(60 \mathrm{mg} / \mathrm{kg})$ & $0.36 \pm 0.02^{*}$ & 20.0 \\
Haliclona $\mathrm{sp.}(90 \mathrm{mg} / \mathrm{kg})$ & $0.32 \pm 0.02 * * *$ & 28.9 \\
D. reticulatus $(60 \mathrm{mg} / \mathrm{kg})$ & $0.37 \pm 0.01$ & 17.8 \\
D. reticulatus $(90 \mathrm{mg} / \mathrm{kg})$ & $0.33 \pm 0.01 * * *$ & 26.7 \\
\hline
\end{tabular}

The paw edema $(\mathrm{mL})$ values are expressed as mean \pm SEM. All extracts and saline (control group) were administered by oral pathway ( $\mathrm{n}=8$ animals/group). Diclofenac was administrated by intraperitoneal pathway. $* * * \mathrm{p}<0.001 ; * * \mathrm{p}<0.01$; indicates statistical difference when compared to control (one-way ANOVA followed by Tukey post hoc test).

Marine sponges to the order Verongida, that includes Aplysina species are a rich source of naturally occurring bromide-containing alkaloids, derived from the tyrosine (bromotyrosine-derived alkaloids) ${ }^{36-38}$. These metabolites have been described as microbicides and antitumorals ${ }^{36}$, however, the anti-inflammatory effects of these compounds are poorly studied. Some years ago, Medeiros et al. ${ }^{10}$ reported the antiinflammatory activity of 11-oxoaerothionin, a bromotyrosine-derivated alkaloid isolated from the marine sponge Aplysina fistularis in culture of macrophages. Moreover, the authors showed that the anti-inflammatory mechanism of this compound seems to be related to the inhibition of $\mathrm{NO}$ production, inflammatory cytokines and $\mathrm{PGE}_{2}$. Chemical studies from the crude extract of A. caissara showed the presence of bromotyrosinederivated alkaloids: caissarine A, B and C; agelocaissarines A1, A2, B1, B2; fistularin-3 and 11-hydroxyaerothionin ${ }^{37,39}$. Based on this studies we can suggest that this class of compounds may be responsible for the anti-inflammatory and antinociceptive effects of $A$. caissara observed in this study and in our previous work from Azevedo et al ${ }^{13}$.

In addition to A. caissara, the extract of Haliclona sp also presented anti-inflammatory activity in the experimental model. Corroborating our results, Koh and Shin ${ }^{40}$ recently demonstrated that an extract from Haliclona sp. decreases the NO production and IL-1 $\beta$ in macrophages stimulated with lipopolysaccharide (LPS) in vitro. Previous chemical studies of marine sponges belonging the genus Haliclona lead to the isolation of several secondary metabolites including alkaloids, macrolides, steroids, peptides, polyacetylenes, polyketides and halogenated derivates ${ }^{41}$. Randazzo et al. ${ }^{18}$ attributed the antiinflammatory activity of Haliclona sp. to two peptides (halipeptins A and B) that showed a very strong anti-inflammatory activity, causing $60 \%$ reduction of edema in mice at the dose of $300 \mathrm{mg} / \mathrm{kg}$. Another study investigated the effects of $\beta$-carboline alkaloid manzamines isolated from Haliclona sp. in LPS-activated rat microglia. They showed that 
this compound modulates the thromboxane $\mathrm{A}_{2}$ and superoxide anion production and can be a potentially useful anti-inflammatory agent to treat neurodegenerative disease ${ }^{42}$.

The specie $D$. reticulatum is less studied among the species analyzed in this study. Literature data show that sponges of the genus Dragmacidon present piperazine alkaloid derivates and $\beta$-carboline alkaloids, some of them are characterized by possessing potent anti-inflammatory and antitumour activities ${ }^{43}$. Recently, Abou-Hussein et al. ${ }^{44}$ isolated one new nucleoside (dragmacidoside) and other compounds (adenosine, iosine, deoxycytidine, methyl-a-D-glucopyranoside, clionasterol, stigmasterol, campesterol and brassicasterol) from the Red Sponge Dragmacidon coccinea. The authors also showed that a chloroform fraction demonstrated significant anti-inflammatory activity in in the carrageenan-induced hind paw oedema in rats. To our knowledge, this is the first experimental study that demonstrates that $D$. reticulatum present anti-inflammatory and antinociceptive effects.

\section{CONCLUSIONS}

In summary, our results demonstrate that the extracts obtained from marine sponges $A$. caissara, Haliclona sp. and $D$. reticulatum exhibit analgesic and anti-inflammatory effects against some classical models of nociception and inflammation in mice. Even though a more exhaustive pharmacological investigation on the extracts of A. caissara, Haliclona sp. and D. reticulatus is needed to characterize the exact target(s) of the compounds, it is clear that the extracts display anti-inflammatory effect in vivo. These findings encourage further pharmacological studies not only to evidence the action mechanism of the extract but also to isolate active compounds found in sponge extracts.

\section{REFERENCES}

1. Blunden G. Biologically Active Compounds from Marine Organisms. 2001;94(November 2000):89-94.

2. Belarbi EH, Contreras Gómez A, Chisti Y, García Camacho F, Molina Grima E. Producing drugs from marine sponges. Biotechnol Adv. 2003;21(7):585-98.

3. Voultsiadou Eleni E. Therapeutic properties and uses of marine invertebrates in the ancient Greek world and early Byzantium. J Ethnopharmacol. 2010;130(2):237-47.

4. De Alencar DB, Da Silva SR, Pires-Cavalcante KMS, De Lima RL, Pereira FN, De Sousa $\mathrm{MB}$, et al. Antioxidant potential and cytotoxic activity of two red seaweed species, amansia multifida and meristiella echinocarpa, from the coast of Northeastern Brazil. An Acad Bras Cienc. 2014;86(1):251-63.

5. Mayer AMS, Rodríguez AD, Taglialatela-Scafati O, Fusetani N. Marine pharmacology in 2009-2011: Marine compounds with antibacterial, antidiabetic, antifungal, anti-inflammatory, antiprotozoal, antituberculosis, and antiviral activities; affecting the immune and nervous systems, and other miscellaneous mechanisms of . Mar Drugs. 2013;11(7):2510-73.

6. Aneiros A, Garateix A. Bioactive peptides from marine sources: Pharmacological properties and isolation procedures. Vol. 803, Journal of Chromatography B: Analytical Technologies in the Biomedical and Life Sciences. 2004. p. 41-53.

7. Anjum K, Abbas SQ, Shah SAA, Akhter N, Batool S, Hassan SSU. Marine sponges as a drug treasure. Vol. 24, Biomolecules and Therapeutics. 2016. p. 347-62.

8. Kijjoa A, Sawangwong P. Drugs and Cosmetics from the Sea. Mar Drugs [Internet]. 2004;2(2):73-82.

9. El-Shitany NA, Shaala LA, Abbas AT, Abdel-dayem UA, Azhar EI, Ali SS, et al. Evaluation of the anti-inflammatory, antioxidant and immunomodulatory effects of the organic extract of the red sea marine sponge xestospongia testudinaria against carrageenan induced rat paw 
inflammation. PLoS One. 2015;10(9):1-16.

10. De Medeiros AI, Gandolfi RC, Secatto A, Falcucci RM, Faccioli LH, Hajdu E, et al. 11Oxoaerothionin isolated from the marine sponge Aplysina fistularis shows anti-inflammatory activity in LPS-stimulated macrophages. Immunopharmacol Immunotoxicol. 2012;34(6):919-24.

11. Keyzers RA, Davies-Coleman MT. Anti-inflammatory metabolites from marine sponges. Chem Soc Rev [Internet]. 2005;34(4):355-65.

12. D'Orazio N, Gammone MA, Gemello E, De Girolamo M, Cusenza S, Riccioni G. Marine bioactives: Pharmacological properties and potential applications against inflammatory diseases., Marine Drugs. 2012; 10: p. 812-33.

13. Azevedo LG, Peraza GG, Lerner C, Soares A, Murcia N, Muccillo-Baisch AL. Investigation of the anti-inflammatory and analgesic effects from an extract of Aplysina caissara, a marine sponge. Fundam Clin Pharmacol. 2008;22(5):549-56.

14. Rashid MA, Gustafson KR, Boswell JL, Boyd MR. Haligramides A and B, two new cytotoxic hexapeptides from the marine sponge Haliclona nigra. J Nat Prod. 2000;63(7):956-9.

15. Mahdian D, Iranshahy M, Shakeri A, Hoseini A, Yavari H, Nazemi M, et al. Cytotoxicity evaluation of extracts and fractions of five marine sponges from the Persian Gulf and HPLC fingerprint analysis of cytotoxic extracts. Asian Pac J Trop Biomed. 2015;5(11):896-901.

16. Wattanadilok R, Sawangwong P, Rodrigues C, Cidade H, Pinto M, Pinto E, et al. Antifungal activity evaluation of the constituents of Haliclona baeri and Haliclona cymaeformis, collected from the Gulf of Thailand. Mar Drugs. 2007;5(2):40-51.

17. Clark RJ, Garson MJ, Hooper JNA. Antifungal alkyl amino alcohols from the tropical marine sponge Haliclona n. sp. J Nat Prod. 2001;64(12):1568-71.

18. Randazzo A, Bifulco G, Giannini C, Bucci M, Debitus C, Cirino G, et al. Halipeptins A and B: Two novel potent anti-inflammatory cyclic depsipeptides from the Vanuatu marine sponge Haliclona species. J Am Chem Soc. 2001;123(44):10870-6.

19. Hara S, Makino K, Hamada Y. Total synthesis of halipeptin A, a potent anti-inflammatory cyclodepsipeptide from a marine sponge. Tetrahedron Lett. 2006;47(7):1081-5.

20. Mora Cristancho JA, Newmark Umbreit F, Santos-Acevedo M, Sánchez Nieves J. Evaluación de extractos de esponjas marinas como nuevas fuentes de sustancias antimicrobianas. Rev Esp Quimioter. 2008;21(3):174-9.

21. Pinheiro UDS, Hajdu E. Shallow-water Aplysina Nardo (Aplysinidae, Verongida, Demospongiae) from the São Sebastião Channel and its environs (Tropical southwestern Atlantic), with the description of a new species and a literature review of other brazilian records of the genus. Rev Bras Zool. 2001;18(1):143-60.

22. Azevedo LG, Muccillo-Baisch AL, Filgueira D de MVB, Boyle RT, Ramos DF, Soares AD, et al. Comparative cytotoxic and anti-tuberculosis activity of Aplysina caissara marine sponge crude extracts. Comp Biochem Physiol - C Toxicol Pharmacol. 2008;147(1):36-42.

23. Koster, R., Anderson, M. and De Beer EJ. Acetic Acid for Analgesic Screening. Fed Proc. 1959;18:412-7.

24. Hunskaar S, Hole K. The formalin test in mice: dissociation between inflammatory and noninflammatory pain. Pain. 1987;30(1):103-14.

25. Süleyman H, Yildirim D, Aslan A, Göçer F, Gepdiremen A, Güvenalp Z. An investigation of the antiinflammatory effects of an extract from Cladonia rangiformis HOFFM. Biol Pharm Bull [Internet]. 2002;25(1):10-3.

26. Thomazzi SM, Ribeiro RA, Campos DI, Cunha FQ, Ferreira SH. Tumor necrosis factor, interleukin-1 and interleukin-8 mediate the nociceptive activity of the supernatant of LPSstimulated macrophages. Mediators Inflamm. 1997;6(3):195-200.

27. Duarte IDG, Nakamura M, Ferreira SH. Participation of the sympathetic system in acetic acid-induced writhing in mice. Brazilian J Med Biol Res. 1988;21(2):341-3.

28. Collier HO, Dinneen LC, Johnson CA, Schneider C. The abdominal constriction response and its suppression by analgesic drugs in the mouse. Br J Pharmacol Chemother. 1968;32(2):295-310.

29. Barros WM, Rao VSN, Silva RM, Lima JCS, Martins DTO. Anti-inflammatory effect of the ethanolic extract from Bowdichia virgilioides H.B.K stem bark. An Acad Bras Cienc. 2010;82(3):609-16. 
30. Santos EN, Lima JCS, Noldin VF, Cechinel-Filho V, Rao VSN, Lima EF, et al. Antiinflammatory, antinociceptive, and antipyretic effects of methanol extract of cariniana rubra stem bark in animal models. An Acad Bras Cienc. 2011;83(2):557-66.

31. Tjølsen A, Berge O-G, Hunskaar S, Rosland JH, Hole K. The formalin test: an evaluation of the method. Pain [Internet]. 1992;51(1):5-17.

32. Shibata M, Ohkubo T, Takahashi H, Inoki R. Modified formalin test: characteristic biphasic pain response. Pain. 1989;38(3):347-52.

33. Yaksh TL, Ozaki G, McCumber D, Rathbun M, Svensson C, Malkmus S, et al. An automated flinch detecting system for use in the formalin nociceptive bioassay. J Appl Physiol [Internet]. 2001;90(6):2386-402.

34. Chichorro JG, Lorenzetti BB, Zampronio AR. Involvement of bradykinin, cytokines, sympathetic amines and prostaglandins in formalin-induced orofacial nociception in rats. $\mathrm{Br} \mathrm{J}$ Pharmacol. 2004;141(7):1175-84.

35. Moore PK, Oluyomi AO, Babbedge RC, Wallace P, Hart SL. L-N(G)-nitro arginine methyl ester exhibits antinociceptive activity in the mouse. Br J Pharmacol. 1991;102(1):198-202.

36. Blunt JW, Copp BR, Keyzers RA, Munro MHG, Prinsep MR. Marine natural products. Nat Prod Rep [Internet]. 2015;32(2):116-211.

37. Saeki BM, Granato AC, Berlinck RGS, Magalhães A, Schefer AB, Ferreira AG, et al. Two unprecedented dibromotyrosine-derived alkaloids from the Brazilian endemic marine sponge Aplysina caissara. J Nat Prod. 2002;65(5):796-9.

38. Silva MM, Bergamasco J, Lira SP, Lopes NP, Hajdu E, Peixinho S, et al. Dereplication of bromotyrosine-derived metabolites by LC-PDA-MS and analysis of the chemical profile of 14 aplysina sponge specimens from the Brazilian coastline. Aust J Chem. 2010;63(6):886-94.

39. De Lira TO, Berlinck RGS, Nascimento GGF, Hajdu E. Further dibromotyrosine-derived metabolites from the marine sponge Aplysina caissara. J Braz Chem Soc. 2006;17(7):1233-40.

40. Koh S, Shin H-S. The Anti-Rotaviral and Anti-Inflammatory Effects of Hyrtios and Haliclona Species. J Microbiol Biotechnol. 2016;26:2006-11.

41. Al-Massarani S, El-Gamal A, Al-Said M, Abdel-Kader M, Ashour A, Kumar A, et al. Studies on the red sea sponge Haliclona sp. for its chemical and cytotoxic properties. Pharmacogn Mag [Internet]. 2016;12(46):114.

42. Mayer AMS, Hall ML, Lynch SM, Gunasekera SP, Sennett SH, Pomponi SA. Differential modulation of microglia superoxide anion and thromboxane B2 generation by the marine manzamines. BMC Pharmacol. 2005;5:1-13.

43. Pedpradab S, Edrada RA, Ebel R, Wray V, Proksch P. New $\beta$-carboline alkaloids from the Andaman Sea sponge Dragmacidon sp. J Nat Prod. 2004;67(12):2113-6.

44. Abou-Hussein DR, Badr JM, Youssef DTA. Dragmacidoside: A new nucleoside from the red sea sponge dragmacidon coccinea. Nat Prod Res. 2014;28(15):1134-41. 